\title{
ARTIKELEN
}

\section{Toenemende publieke steun voor meer eigen verantwoordelijkheid in de zorg?}

\author{
Ellen Verbakel
}

\begin{abstract}
De Nederlandse overheid streeft naar een participatiesamenleving. Zo heeft ze sinds de invoering van de Wet maatschappelijke ondersteuning (Wmo) ingezet op een grotere eigen verantwoordelijkheid bij het inzetten van zorg. Weerspiegelt de publieke opinie deze mentaliteitsverandering? Dit artikel gaat na (a) in hoeverre de publieke opinie over verantwoordelijkheid voor ouderenzorg is veranderd tussen 2003 en 2010, (b) welke factoren verklaren waarom sommige mensen deze verantwoordelijkheid het meest bij de overheid en anderen bij familie leggen en (c) welke factoren intra-individuele attitudeveranderingen verklaren. Er is gebruik gemaakt van surveygegevens uit het Netherlands Kinship Panel Study (2003, 2006/07, 2010). ${ }^{1}$ Er blijkt een verschuiving te zijn opgetreden in de publieke opinie in de lijn van het overheidsbeleid: minder verantwoordelijkheid voor de overheid en meer voor de familie. Echter, de meerderheid van de Nederlandse bevolking legt nog steeds de meeste verantwoordelijkheid bij de overheid. Attitudes hangen met name samen met normatieve motieven en in mindere mate met utiliteitsmotieven. Intraindividuele verandering in attituden in de richting van minder overheidsverantwoordelijkheid worden vooral verklaard door normatieve factoren en niet door factoren die gerelateerd zijn aan eigenbelang.
\end{abstract}

\section{Inleiding}

Stimulering van de zelfredzaamheid van de burger is een belangrijk uitgangspunt van hedendaagse kabinetten en komt tot uitdrukking in de recentelijk veel gebezigde term 'participatiesamenleving'. Burgers moeten actief in de samenleving participeren en zijn in eerste instantie zelf (samen met hun netwerk) verantwoordelijk voor de realisatie daarvan; ondersteuning vanuit de overheid is er alleen als het echt nodig is. Deze beleidslijn gaat samen met een decentralisatiebeweging, aangezien gemeenten geacht worden beter maatwerk te kunnen leveren in de ondersteuning aan burgers (ministerie van Binnenlandse Zaken en Koninkrijksrelaties, 2013). Op korte termijn staan grote herzieningen op stapel in verschillende beleidsdomeinen waarin de combinatie van eigen verantwoordelijkheid en decentralisatie nadrukkelijk verwoord wordt: de Participatiewet, de Wet op de

1 De Netherlands Kinship Panel Study is mogelijk gemaakt door toekenning uit Investeringen NWO-groot (480-10-009) en door het Nederlands Interdisciplinair Demografisch Instituut (NIDI), Universiteit van Utrecht, Universiteit van Amsterdam, Universiteit van Tilburg (wave 1 en 2) en ook Erasmus Universiteit Rotterdam (wave 3). 
jeugdzorg en de nieuwe Wet maatschappelijke ondersteuning (invoeringen gepland op 1 januari 2015). Nederland staat niet alleen in deze trend naar meer verantwoordelijkheid van de burger en decentralisatie van overheidstaken; ze past in een bredere internationale visie zoals die van de 'Big Society' in het Verenigd Koninkrijk.

Op het gebied van de zorg, trad de overheid reeds in 2007 deze nieuwe richting in met de invoering van de Wet maatschappelijke ondersteuning. Deze wet verwacht van zorgbehoevende burgers dat zij zorg in eerste instantie in hun eigen netwerk zoeken; pas als mantelzorg geen (afdoende) optie is en ook het informele circuit (vrijwilligerswerk) niet ingezet kan worden, kan men een beroep doen op overheidssteun (De Klerk e.a., 2010; Tonkens, 2011). De maatschappelijke implicatie van de Wmo is een grotere behoefte aan de inzet van mantelzorgers (Sadiraj e.a., 2009); een behoefte die de komende jaren verder zal toenemen door de vergrijzende bevolking en de gepaard gaande toenemende zorgvraag. De Wmo omvat daarmee beide principes van 'affectief burgerschap' (Kampen e.a., 2013): eigen verantwoordelijkheid van burgers (niet leunen op voorzieningen van de staat, maar zelf oplossingen zoeken) aangevuld met affectieve solidariteit (actief zorgdragen voor medeburgers).

De verschuiving richting eigen verantwoordelijkheid is niet alleen vernieuwend voor overheid en beleidsmakers; het vraagt ook om een mentaliteitsverandering van de Nederlandse bevolking. Jarenlang waren burgers gewend aan een genereus faciliterende overheid, maar nu en in de toekomst komt steeds meer nadruk te liggen op de inzet van het eigen netwerk. In dit artikel wordt de vraag gesteld in hoeverre de mening van Nederlanders over de verantwoordelijkheid voor de zorg voor hulpbehoevende ouderen veranderd is tussen 2003 en 2010. Vinden we ook in de publieke opinie een verschuiving van de mening dat niet de overheid maar de familie (het eigen netwerk) de taak heeft om te zorgen voor hulpbehoevende ouderen? Een verschuiving van de publieke opinie in de richting van afnemende overheidsverantwoordelijkheid zou kunnen worden opgevat als toenemend draagvlak voor de veranderde overheidsvisie en voor het gezondheidsbeleid dat deze ontwikkelt. Draagvlak onder de bevolking is belangrijk voor een succesvolle en effectieve implementatie van beleid. Enerzijds bepaalt de mate waarin beleid iemands normatieve opvattingen rechtvaardigt, in hoeverre men het beleid legitimeert (Beetham, 1991); als mensen overheidsbeleid legitimeren, zijn ze meer geneigd het te steunen en zich coöperatief op te stellen. Anderzijds kunnen uitvoerders van beleid geneigd zijn zich te laten beïnvloeden door de publieke opinie om weerstand of negatieve reacties te minimaliseren (Van Meter \& Van Hom, 1975); als de publieke opinie niet overeenkomt met de insteek van het beleid, kan de implementatie van het beleid suboptimaal zijn. Kennis van de publieke opinie en inzicht in veranderingen en determinanten ervan zijn voorwaarden om effectief te kunnen handelen en kunnen zo de overheid helpen bij de uitvoering van haar beleidsvoornemens.

Eerder onderzoek heeft laten zien dat eigen verantwoordelijkheid als algemeen principe op veel steun kan rekenen van de Nederlandse bevolking (Dekker \& Den 
Ridder, 2011; Den Ridder \& Dekker, 2012; Van Noije e.a., 2012). Het wordt geassocieerd met positieve effecten zoals meer keuzevrijheid, bewustere en meer betrokken burgers en minder kosten (Dekker \& Den Ridder, 2013). De steun voor eigen verantwoordelijkheid ligt lager als mensen gevraagd wordt naar specifieke beleidsterreinen; dan blijken veel burgers toch een grote rol voor de overheid te zien, vooral omdat ze bang zijn dat zwakkeren de dupe worden en er chaos komt als de overheid zich terugtrekt (Dekker \& Den Ridder, 2013). Relatief weinig steun voor eigen verantwoordelijkheid geldt zeker op het terrein van de gezondheidszorg. Zo heeft onderzoek bijvoorbeeld laten zien dat, op een schaal van 0 (overheid zou helemaal niet verantwoordelijk moeten zijn) tot 100 (overheid zou volledig verantwoordelijk moeten zijn), 'toereikende gezondheidszorg' 83 scoort, terwijl de gemiddelde score over allerlei beleidsterreinen 'slechts' 68 is (data verzameld in 2008/2009) (Den Ridder \& Dekker, 2012).

Bestaande onderzoeksresultaten over meningen omtrent eigen verantwoordelijkheid voor zorg specifiek voor ouderen zijn relatief schaars. Uit het Continu Onderzoek Burgerperspectieven (2001, kwartaal 3) komt naar voren dat $14 \%$ van de Nederlanders de zorg voor ouderen primair bij de familie legt, $34 \%$ primair bij de overheid en $48 \%$ voor een mengvorm opteert; de overigen hebben geen voorkeur (Dekker \& Den Ridder, 2011). Hetzelfde onderzoek laat zien dat slechts een minderheid vindt dat individuen meer eigen verantwoordelijkheid zouden moeten nemen, terwijl een ruime meerderheid juist meer verantwoordelijkheid van de overheid wenst als het gaat om 'dat je als oudere wordt verzorgd'. De Boer en Kooiker (2012) rapporteren op basis van de Enquête Eigen Verantwoordelijkheid, afgenomen in 2012, dat bijna de helft van de Nederlandse bevolking (45\%) het (helemaal) eens is met de stelling dat de zorg voor eenzame ouderen de verantwoordelijkheid van de overheid is, tegen $24 \%$ die het (helemaal) oneens is.

Kortom, op het terrein van de gezondheidszorg en - meer specifiek - de ouderenzorg lijkt de burger een relatief grote rol voor de overheid te zien. Dit suggereert dat er sprake is van een gebrek aan draagvlak voor het overheidsvoornemen eigen verantwoordelijkheid op dit terrein te bevorderen (De Boer \& Kooiker, 2012). Het is nog niet bekend of er wel sprake is van een ontwikkeling in de 'goede' richting, dat wil zeggen een toenemende overeenstemming tussen de uitgangspunten van het beleid en de publieke opinie. Trends in de algemene steun voor het principe 'eigen verantwoordelijkheid' zijn niet erg uitgesproken (Dekker \& Den Ridder, 2011), maar of dit ook geldt voor de toepassing op zorg voor ouderen is niet bekend. Deze studie zal deze kennislacune opvullen. Daarnaast biedt dit onderzoek vernieuwing door individuen over de tijd te volgen om na te gaan welke groepen hun attituden over verantwoordelijkheid voor ouderenzorg hebben aangepast. Deze aanpak biedt het grote voordeel dat er iets sterkere causale uitspraken gedaan kunnen worden over relaties tussen determinanten en attitudes. Respondenten is gevraagd of ze de verantwoordelijkheid voor ouderenzorg vooral een taak voor de overheid of voor de familie vinden. Hierbij wordt de mening dat de taak vooral bij de familie ligt geïnterpreteerd als steun voor de principes van 
eigen verantwoordelijkheid en affectieve solidariteit en dus als steun voor de huidige visie van de overheid.

De vragen die in dit artikel beantwoord zullen worden, luiden: (1) Welke ontwikkeling heeft zich voorgedaan in de publieke opinie omtrent eigen verantwoordelijkheid versus overheidsverantwoordelijkheid voor de zorg voor hulpbehoevende ouderen tussen 2003 en 2010?; (2) Welke factoren verklaren de attitude ten aanzien van verantwoordelijkheid voor de zorg van hulpbehoevende ouderen?; en (3) Welke factoren verklaren intra-individuele veranderingen in de attitude ten aanzien van verantwoordelijkheid voor de zorg van hulpbehoevende ouderen tussen 2003 en $2010 ?$

\section{Theoretische verwachtingen over determinanten van attitudes en attitudeverandering}

Waarom hechten sommige mensen het meest aan overheidsverantwoordelijkheid en anderen juist aan eigen verantwoordelijkheid voor de zorg van hulpbehoevende ouderen? Mogelijke verklarende factoren worden geordend naar twee theoretische mechanismen.

In de eerste plaats wordt aangenomen dat attitudes voortkomen uit dieper liggende waardeoriëntaties (Glenn, 1980). In de context van zorg door familieleden is met name de normatieve overtuiging relevant dat men familie behoort te helpen ('normative kinship obligations'; Rossi \& Rossi, 1990). Hiermee wordt bedoeld dat mensen zich verplicht voelen hun familie te helpen. Deze groep zal de zorgtaak naar verwachting dan ook primair bij de familie leggen. Je zou deze normatieve overtuiging kunnen afzetten tegen een individualistische overtuiging waarin tot uitdrukking komt dat mensen voor zorg niet afhankelijk willen of zouden moeten zijn van familie (Halman, 1996), maar - indien nodig - moeten kunnen aankloppen bij de (onpartijdige) staat. Concrete indicatoren voor deze normatieve overtuiging zijn een meting van familiewaarden, kerkgang en urbanisatiegraad van de woonplaats. De eerste hypothese luidt dat mensen met sterke familiewaarden, regelmatige kerkgangers en mensen die in minder stedelijke gebieden wonen, verantwoordelijkheid voor de zorg van ouderen relatief minder bij de overheid en meer bij de familie leggen.

De tweede groep determinanten komt voort uit utiliteitsmotieven. Eigen verantwoordelijkheid in de zorg voor ouderen heeft niet voor iedereen dezelfde consequenties. Mensen wegen mogelijke voor- en nadelen af voor de persoonlijke situatie en stemmen vervolgens hun voorkeuren af op basis van de uitkomst die het meest in hun eigenbelang is (Battaglio, 2009; Durant \& Legge, 2002). Het utiliteitsargument kan vanuit twee posities beredeneerd worden: vanuit (potentiële) zorgontvangers en vanuit (potentiële) zorgverleners. Vanuit de positie van (potentiële) zorgontvangers - in deze context vooral ouderen - kan beredeneerd worden dat hun belang het best gediend wordt als de verantwoordelijkheid voor zorg bij de overheid ligt, omdat dat zekerheid geeft over de aanwezigheid van 
voorzieningen (Dekker \& Den Ridder, 2013). Over inzet van familie kan men gemiddeld genomen minder zeker zijn en bovendien is deze - indien wel beschikbaar - altijd nog bovenop overheidsvoorzieningen in te zetten. Voor de groep van (potentiële) zorgverleners wordt ten eerste verwacht dat zij die een grotere kans percipiëren om nu of in de toekomst te moeten gaan zorgen voor oudere familieleden, meer belang hebben bij een grotere rol voor de overheid. Mantelzorg wordt immers vaak als belastend ervaren (Pinquart \& Sörensen, 2003), ondanks dat mantelzorg ook positieve ervaringen oplevert (De Boer e.a., 2010). Het gaat hier naar verwachting om mensen wier ouders nog in leven zijn (De Boer e.a., 2010) en om vrouwen, aangezien voor zorgtaken vooral een beroep op vrouwen wordt gedaan (Tonkens \& Duyvendak, 2013). Ten tweede wordt verondersteld dat de mate waarin mantelzorg verlenen sterk nadelige consequenties heeft voor een (potentiële) zorgverlener bijdraagt aan zijn of haar afweging. Verwacht wordt dat degenen die de minste hulpbronnen hebben in termen van tijd, gezondheid en netwerk, de meeste belemmeringen ervaren bij het zelf zorgen voor familie en dus meer voorstander zullen zijn van een grote rol voor de overheid. Hierbij gaat het om mensen met een (drukke) baan, een eigen slechte gezondheid of met weinig broers en zussen of kinderen en een partner om zorg of taken mee te verdelen. Een derde verwachting refereert aan gepercipieerde risico's van bepaalde scenario's. Bouwen of vertrouwen op anderen brengt risico's met zich mee, want er is altijd onzekerheid of anderen misbruik zullen maken van eigen inspanningen (Newton, 1999; Putnam, 2000). Risico's zijn kleiner als mensen eventuele vervelende gevolgen gemakkelijker kunnen dragen of beter kunnen inschatten; dit geldt bijvoorbeeld voor mensen met een hoog inkomen of hoog opleidingsniveau (Dohmen e.a., 2010). Het sociale vertrouwen dat hieruit voortkomt, maakt dat zij minder bang zijn voor eventueel misbruik en durven daarom meer uit te gaan van eigen verantwoordelijkheid van burgers (Den Ridder \& Dekker, 2012). Samenvattend volgt uit de theoretische overweging van eigenbelang van (potentiële) zorgontvangers en zorgverleners de volgende hypothese: verantwoordelijkheid voor de zorg van hulpbehoevende ouderen wordt relatief meer bij de overheid dan bij de familie gelegd door ouderen, mensen met een (voltijd) baan, met een relatief slechte gezondheid, zonder partner, met weinig of geen kinderen, broers en zussen, met in leven zijnde ouders, met een laag inkomen, met een laag opleidingsniveau en door vrouwen.

Opgemerkt dient te worden dat voor sommige verklarende factoren wellicht beide theoretische mechanismen opgeld doen. Zo kunnen hoogopgeleiden enerzijds de gevolgen van eigen verantwoordelijkheid beter dragen (samengaand met meer steun voor eigen verantwoordelijkheid), maar zijn zij anderzijds vaak meer individualistisch en minder familiegericht ingesteld (Felling e.a., 2000) (samengaand met minder steun eigen verantwoordelijkheid). Ouderen hebben belang bij ruime overheidsvoorzieningen (minder steun voor eigen verantwoordelijkheid), maar onderschrijven vaak wel de familiegerichte waarden (meer steun voor eigen verantwoordelijkheid). Vrouwen, ten slotte, kunnen verwachten dat eigen verantwoordelijkheid veelal op hun bordje terecht komt (minder steun voor eigen verantwoordelijkheid), maar staan tevens bekend als vervullers van de 'kinkeeper' rol 
(Rosenthal, 1985) waaruit een sterke familiegerichtheid blijkt (meer steun voor eigen verantwoordelijkheid). Dit onderzoek zal niet toetsen via welke mechanismen deze determinanten attitudes beïnvloeden; de beschreven mechanismen geven enkel richting aan de interpretatie van de gevonden verbanden.

Naast de vraag hoe we opvattingen over verantwoordelijkheid voor zorg kunnen verklaren, gaat dit onderzoek ook na welke factoren verklaren waarom sommige mensen hun mening hebben aangepast tussen 2003 en 2010 en in welke richting. Verwacht wordt dat bovenstaande factoren tevens voorspellend zullen zijn voor de kans op aanpassing van attitudes. Onder invloed van de aandacht die er in de politieke discussie en het publieke debat voor dit thema is, wordt verwacht dat mensen die sterk familiegericht zijn nog verder in de richting van familieverantwoordelijkheid zullen zijn opgeschoven. Daarnaast wordt verondersteld dat mensen zich door de aandacht voor eigen verantwoordelijkheid sterker bewust zijn geworden van de consequenties ervan voor hun eigen situatie. Verwacht wordt dat, als reactie daarop, met name mensen voor wie overheidsverantwoordelijkheid in hun eigen belang is, hun opvatting hebben aangepast in de richting van meer overheidsverantwoordelijkheid.

\section{Materiaal en aanpak}

\subsection{Data en meetinstrumenten}

De gegevens zijn afkomstig van drie verzamelingen van de Netherlands Kinship Panel Study: 2003, 2006/07 en $2010^{2}$ (Dykstra e.a., 2005; Dykstra e.a., 2012; Merz e.a., 2012). Doel van de dataverzameling is het bestuderen van familierelaties vanuit een dynamisch en multi-actor perspectief; de studie is daarom opgezet als een panel en ondervraagt naast de respondent ook diens familieleden. De eerste dataverzameling betreft een aselecte steekproef van individuen in de leeftijd van 18 tot 79 jaar in particuliere huishoudens in Nederland. Middels een face-toface interview en schriftelijke vragenlijst is de respondent gevraagd naar zijn of haar leven, familie, familierelaties en een aantal specifieke opvattingen. De respons bedraagt $37,1 \%$; in totaal hebben 8.161 respondenten deelgenomen. $74,6 \%$ van deze respondenten heeft deelgenomen aan de tweede dataverzameling $(\mathrm{N}=6.091)$ en $72,1 \%$ van de respondenten op dit tweede meetmoment heeft deelgenomen aan de derde dataverzameling $(\mathrm{N}=4.390)$. In dit onderzoek zijn de data gewogen naar een individuele steekproef die qua huishoudtype, geslacht, leeftijd, regio en urbanisatiegraad representatief is voor de populatie in de betreffende periode. De drie dataverzamelingen zijn gecombineerd tot een bestand met 18.642 waarnemingen. Hiervan zijn alleen respondenten geselecteerd die een geldige waarde hebben op de afhankelijke variabele (dit betekent een verlies van 1.140 respondenten, met name omdat zij de schriftelijke vragenlijst niet hebben ingevuld) en op de onafhankelijke variabelen met uitzondering van de variabele inkomen (dit betekent een verlies van 57 respondenten).

2 Data zijn verzameld tussen oktober 2002 en januari 2004 (wave 1), tussen september 2006 en juni 2007 (wave 2) en tussen april 2010 en februari 2011 (wave 3). 
De attitude waar het in deze studie om gaat, is als volgt gemeten: 'Hieronder wordt een aantal zaken genoemd die geregeld moeten worden in ons land. Vindt u deze zaken meer een taak voor de familie of meer een taak voor de overheid?' Eén van de zaken die de respondent voorgelegd heeft gekregen, is: 'zorg voor hulpbehoevende ouderen'. Op een vierpuntsschaal kon de respondent aangegeven of dit vooral of (iets) meer een taak voor de overheid of juist vooral of (iets) meer een taak voor de familie is. Het vaststellen van ontwikkelingen in deze attitude over de drie meetmomenten gebeurt aan de hand van beschrijvingen van de procentuele verdelingen en van gemiddelden. Voor het berekenen van deze gemiddelden zijn de antwoordcategorieën dusdanig gehercodeerd dat scores lopen van $-1,5$ (vooral een taak voor de familie), -0,5 ((iets) meer een taak voor de familie), 0,5 ((iets) meer een taak voor de overheid) en 1,5 (vooral een taak voor de overheid). Een positieve score betekent dat de respondent de verantwoordelijkheid voor de zorg van hulpbehoevende ouderen vooral bij de overheid neerlegt en een negatieve score dat deze de verantwoordelijkheid hiervoor vooral bij de familie legt.

Er worden drie factoren onderscheiden die indicatief zijn voor de normatieve overtuiging dat men familie behoort te helpen. In de eerste plaats is een schaal geconstrueerd van familiewaarden die uitdrukking geven aan een normatieve verplichting altijd voor familieleden klaar te staan. Hiertoe is de gemiddelde score berekend van 12 items $^{3}$, gemeten op een vijfpuntsschaal (Cronbach's alpha = 0,85 ); een hoge score betekent dat men sterke familiewaarden heeft. Daarnaast worden kerkgang (nooit/vrijwel nooit versus soms/vaak) en urbanisatiegraad (schaal in vijf stappen oplopend van niet geürbaniseerd tot zeer sterk geürbaniseerd) als indicatoren voor sterke familienormen gezien.

Indicatoren die voortvloeien uit utiliteitsoverwegingen zijn de volgende. De eerste indicator betreft leeftijd van de respondent ten tijde van het interview. Er wordt onderscheid gemaakt tussen respondenten van wie beide ouders overleden zijn, van wie één ouder in leven is en van wie beide ouders in leven zijn. Vrouwen worden vergeleken met mannen. Arbeidsparticipatie wordt gemeten met dummyvariabelen: geen werk, een parttime baan (1-34 uur) en een fulltime baan (35 uur of meer). Eigen gezondheid is een subjectieve evaluatie van algemene gezondheid variërend van zeer slecht tot uitstekend (vijfpuntsschaal). Het hebben van een partner, het aantal kinderen en het aantal broers en zussen zijn metingen voor het potentiële steunnetwerk waarbinnen zorg verdeeld kan worden. Huishoudinkomen weerspiegelt wat partners gezamenlijk netto per maand binnenbrengen aan inkomen en uitkeringen. Missende waarden (15,2\%) zijn ingevuld met het gemiddelde netto huishoudinkomen; een dummy variabele waarop respondenten die oorspronkelijk een missende waarde hadden een 1 scoren, wordt opgenomen in de analyse. Opleidingsniveau is omgezet van een nominaal naar een interval meetniveau door uit te drukken hoeveel jaren nodig zijn om het betreffende

3 Voorbeelden van items zijn: Familieleden horen voor elkaar klaar te staan, ook als ze elkaar niet aardig vinden; Kinderen zouden voor hun zieke ouders moeten zorgen; Ouders horen hun volwassen kinderen te ondersteunen als die dat nodig hebben. 
Tabel 1: Beschrijvende statistieken afhankelijke en onafhankelijke variabelen

\begin{tabular}{|c|c|c|c|c|c|c|}
\hline & \multicolumn{2}{|c|}{2003} & \multicolumn{2}{|c|}{$2006 / 07$} & \multicolumn{2}{|c|}{2010} \\
\hline & gem. & st.dev. & gem. & st.dev. & gem. & st.dev. \\
\hline $\begin{array}{l}\text { Attitude: zorg voor hulpbehoevende } \\
\text { ouderen is vooral een taak voor de } \\
\text { overheid (versus familie) }(-1.5-1.5)\end{array}$ & 0,59 & 0,74 & 0,58 & 0,72 & 0,47 & 0,72 \\
\hline Sterke familiewaarden (0-4) & 2,29 & 0,60 & 2,23 & 0,56 & 2,15 & 0,56 \\
\hline Kerkgang $(0 / I)$ & 0,43 & & 0,35 & & 0,36 & \\
\hline Urbanisatiegraad (0-4) & 2,16 & $\mathrm{I}, 3 \mathrm{I}$ & 2,17 & 1,28 & $\mathrm{I}, 80$ & I,57 \\
\hline Leeftijd (I8-89) & 44,85 & 15,75 & 47,95 & 15,73 & 52,22 & 15,86 \\
\hline \multicolumn{7}{|l|}{ Situatie ouders } \\
\hline Beide ouders overleden $(0 / I)$ & 0,32 & & 0,35 & & 0,42 & \\
\hline Eén ouder in leven $(0 / I)$ & 0,25 & & 0,24 & & 0,22 & \\
\hline Beide ouders in leven $(0 / 1)$ & 0,43 & & 0,40 & & 0,35 & \\
\hline Vrouw $(0 / 1)$ & 0,51 & & $0,5 \mathrm{I}$ & & 0,50 & \\
\hline \multicolumn{7}{|l|}{ Arbeidsparticipatie } \\
\hline Niet werkzaam (0/I) & 0,35 & & 0,35 & & 0,38 & \\
\hline Deeltijd werkend $(0 / I)$ & 0,28 & & 0,30 & & 0,29 & \\
\hline Voltijd werkend $(0 / \mathrm{I})$ & 0,38 & & 0,36 & & 0,34 & \\
\hline Gezondheid (0-4) & 3,07 & 0,79 & 3,05 & $0,7 \mathrm{I}$ & 2,96 & 0,75 \\
\hline Partner $(0 / I)$ & 0,76 & & 0,79 & & 0,79 & \\
\hline Aantal kinderen (0-14) & 1,59 & ।,47 & ।,7। & 1,44 & I,97 & 1,60 \\
\hline Aantal broers en zussen $(0-22)$ & 3,07 & 2,52 & 3,04 & 2,46 & 3,03 & 2,46 \\
\hline $\begin{array}{l}\text { Netto maandelijks huishoudinkomen } \\
(\times 100 \text { Euro) }(0-300)\end{array}$ & 20,08 & $|5,3|$ & 25,22 & 15,30 & 29,36 & 16,01 \\
\hline $\begin{array}{l}\text { Oorspronkelijk missende waarde } \\
(0 / I)\end{array}$ & 0,13 & & 0,18 & & 0,12 & \\
\hline Opleidingsniveau in jaren (5-2I) & 12,28 & 3,16 & 12,64 & 3,16 & 12,77 & 3,23 \\
\hline
\end{tabular}

Bron: NKPS 2003 ( $N=7.383), 2006 / 07(N=5.679)$ en 2010 ( $N=4.232)$, gewogen data

niveau af te ronden (van 5 jaar voor het niet afmaken van de lagere school tot 21 jaar voor een postacademische opleiding. Tabel 1 toont de beschrijvende statistieken van de onafhankelijke en afhankelijke kenmerken.

\subsection{Methoden}

De trendvraag wordt beantwoord met beschrijvingen van ontwikkelingen in de attitude tussen 2003, 2006/2007 en 2010. Dit gebeurt zowel in termen van procentuele verdelingen als in termen van gemiddelden.

Het antwoord op de vraag welke groepen zorg voor ouderen meer een taak voor de overheid (dan de familie) vinden, wordt verkregen middels ordinairy least squa- 
res regressieanalyse. Als afhankelijke variabelen worden hiervoor de items gebruikt die gehercodeerd zijn tot een schaal van -1.5 (vooral een taak voor de familie) tot 1.5 (vooral een taak voor de overheid). Om te corrigeren voor het feit dat veel respondenten twee of drie keer informatie leveren wordt een clusteroptie op respondentnummer toegepast.

De beantwoording van de laatste vraag, over verklarende factoren van intra-individuele veranderingen in attitude, behoeft een longitudinale analyseaanpak. Hiertoe is een selectie gemaakt van respondenten die aan alle meetmomenten hebben deelgenomen $(\mathrm{N}=4.016)$. Voor iedere respondent is vastgesteld of ze hun opvatting over verantwoordelijkheid voor zorg voor ouderen tussen twee opeenvolgende meetmomenten hebben bijgesteld en in welke richting. Zo kunnen drie groepen onderscheiden worden: stabiel, opgeschoven in de richting van meer familieverantwoordelijkheid, opgeschoven in de richting van meer overheidsverantwoordelijkheid. Middels multinomiale regressieanalyse wordt de associatie geschat tussen de onafhankelijke variabelen en de kans om tot de ene groep versus de andere groep te behoren. Door de onafhankelijke variabelen te meten aan het begin van de periode (bijvoorbeeld 2003) is zeker dat deze in de tijd vooraf zijn gegaan aan de attitudeverandering die plaatsvond gedurende de periode (in dit voorbeeld: 2003 en 2006/07). Daarnaast wordt gewaarborgd dat de geschatte effecten onafhankelijk zijn van de uitgangspositie van de respondent door constant te houden voor de attitude die de respondent had bij aanvang van de periode. Voor iedere respondent wordt voor twee periodes (2003-2006/07 en 2006/07-2010) de verandering geregistreerd. Omdat dit impliceert dat waarnemingen binnen hetzelfde individu niet onafhankelijk zijn, wordt wederom een clusteroptie toegepast. ${ }^{4}$

\section{Resultaten}

\subsection{Beschrijving trend}

Tabel 2 toont de procentuele verdeling van antwoorden op de vraag bij wie primair de taak ligt voor de zorg voor hulpbehoevende ouderen in de jaren 2003, 2006/07 en 2010. De verantwoordelijkheid wordt gedurende de jaren iets minder bij de overheid gelegd. Het percentage mensen dat vindt dat de zorg voor ouderen vooral een taak voor de overheid is, is gedaald van $30,2 \%$ naar $21,7 \%$. De daling in de categorie 'vooral een taak voor de overheid' is gepaard gegaan met stijgingen in de categorieën 'iets meer een taak voor de overheid' en 'iets meer een taak voor de familie'. Het onderste deel van Tabel 2 geeft de trend in opvattingen weer in termen van gemiddelden, waarbij positieve scores staan voor overheidsverantwoordelijkheid en negatieve scores voor familieverantwoordelijkheid. De gemiddelden

4 In theorie is het mogelijk dat de invloed van een determinant op de kans dat een respondent in een bepaalde richting verandert en niet in een andere richting, anders is in de periode 2003-2006/07 dan in de periode 2006/07-2010. Dit is getest middels interactietermen, maar bleek slechts in één uitzondering het geval te zijn. Analyses zijn daarom niet apart voor de twee periodes gerapporteerd. 
Tabel 2: $\quad$ Procentuele verdeling en gemiddelde scores van attituden ten aanzien van de verantwoordelijkheid voor zorg tussen 2003 en 2010

\begin{tabular}{|c|c|c|c|c|}
\hline $\begin{array}{l}\text { Zorg voor hulpbehoevende } \\
\text { ouderen is ... }\end{array}$ & 2003 & $2006 / 07$ & 2010 & $\begin{array}{c}\text { Verschil } \\
2010-2003\end{array}$ \\
\hline Vooral een taak voor de overheid & $30,2 \%$ & $28,6 \%$ & $21,7 \%$ & $-8,5 \%$ \\
\hline $\begin{array}{l}\text { (lets) meer een taak voor de over- } \\
\text { heid }\end{array}$ & $50,8 \%$ & $52,7 \%$ & $55,8 \%$ & $5,0 \%$ \\
\hline (lets) meer een taak voor de familie & $16,8 \%$ & $16,8 \%$ & $19,9 \%$ & $3,1 \%$ \\
\hline Vooral een taak voor de familie & $2,2 \%$ & $1,9 \%$ & $2,6 \%$ & $0,4 \%$ \\
\hline Gemiddelde score & 0,59 & 0,58 & 0,47 & $-0,12$ \\
\hline $\begin{array}{l}\text { (-I,5 vooral taak voor de familie; I,5 } \\
\text { vooral taak voor de overheid) }\end{array}$ & & & & \\
\hline
\end{tabular}

Bron: NKPS 2003 ( $N=7.383), 2006 / 07(N=5.679)$ en $2010(N=4.232)$, gewogen data

bevestigen de zojuist beschreven trend: de attitude ten aanzien van verantwoordelijkheid voor de zorg voor ouderen is verschoven in de richting van de familie.

De sterkste ontwikkelingen hebben zich voorgedaan tussen 2006/07 en 2010; dat wil zeggen na invoering van de Wmo. Overigens is het belangrijk op te merken dat nog steeds de overgrote meerderheid van de Nederlanders vindt dat de overheid de grootste taak heeft in de zorg voor hulpbehoevenden en niet de familie (ruim driekwart; zie ook de positieve getallen in het onderste deel van tabel 2). Dit strookt met bevindingen in eerdere onderzoeken waaruit bleek dat het enthousiasme voor eigen verantwoordelijkheid relatief klein is als het gaat om gezondheidszorg (Den Ridder \& Dekker, 2012).

\subsection{Determinanten van attituden}

Het antwoord op de vraag welke factoren samenhangen met attituden ten aanzien van verantwoordelijkheid voor de zorg van hulpbehoevende ouderen kan gevonden worden in tabel 3. De in tabel 2 gerapporteerde patronen komen ook hier terug: Nederlanders dichten gemiddeld genomen de overheid een grotere taak toe dan de familie (intercept $=0,738$ ) en er heeft zich een verschuiving voorgedaan van een verantwoordelijkheid van de overheid richting een verantwoordelijkheid van de familie. Ten opzichte van de referentiecategorie van 2003 ligt de attitude ten aanzien van verantwoordelijkheid voor de ouderenzorg in 2010 significant minder in de richting van de overheid $(b=-0,161)$. Deze bevinding blijkt onafhankelijk van eventuele veranderingen in de bevolkingssamenstelling in dezelfde periode (voor zover deze veranderingen betrekking hebben op kenmerken die opgenomen zijn in de analyse), want daarvoor is nu gecontroleerd. De geconstateerde verschuiving blijkt zelfs iets sterker dan reeds geobserveerd in tabel $2(-0,12)$, hetgeen aangeeft dat veranderingen in de compositie van de bevolking de ontwikkeling in attitude zelfs iets gedempt hebben. 
Normatieve factoren blijken duidelijk samen te hangen met attituden ten aanzien van de verantwoordelijkheid voor zorg. Mensen met sterke familiewaarden ('kinship obligation norms') en mensen die regelmatig naar de kerk gaan leggen de verantwoordelijkheid voor ouderenzorg in minder sterke mate bij de overheid en dus meer bij de familie. Zo is het geschatte verschil tussen een respondent met de sterkste en zwakste familiewaarden bijna 1 punt $\left(4^{*} 0,233\right)$ op de attitudeschaal die loopt van $-1,5$ tot 1,5 . Ook al werd verondersteld dat waardeoriëntaties in minder stedelijke gebieden meer zouden aansluiten bij familieverantwoordelijkheid, wordt gevonden dat mensen in minder stedelijke gebieden juist minder verantwoordelijkheid bij de familie leggen, al is de sterkte van het verband zwak.

Verklarende factoren beredeneerd vanuit het principe van eigenbelang hangen slechts tot op zekere hoogte samen met attituden ten aanzien van de verantwoordelijkheid voor ouderenzorg. Eigenbelang lijkt niet geschikt om de attitude van (potentiële) zorgontvangers te verklaren: leeftijd hangt niet samen met opvattingen over verantwoordelijkheid voor ouderenzorg 5 . Het utiliteitsprincipe lijkt eveneens niet op te gaan voor groepen die de grootste kans hebben zorgverlener te zijn of te worden: vrouwen zien ouderenzorg juist minder dan mannen als taak voor de overheid en in vergelijking met hen die geen ouders meer in leven hebben, vinden mensen die nog één ouder in leven hebben dat de zorg voor hulpbehoevende ouderen meer bij de familie moet liggen. Van de factoren die mantelzorg een relatief grote opgave maken, blijkt arbeidsparticipatie niet samen te hangen met attituden, maar blijkt een slechtere gezondheid en een klein netwerk van broers, zussen en kinderen, zoals verwacht, samen te gaan met een voorkeur voor meer overheidsverantwoordelijkheid. Mensen met een partner daarentegen - ook een potentiële kandidaat om zorgtaken mee te delen - leggen de verantwoordelijkheid voor ouderenzorg meer bij de overheid dan mensen zonder partner. Een alternatieve verklaring voor deze bevinding kan liggen in de gepercipieerde kansen om zelf te moeten (gaan) zorgen, aangezien partners een logisch eerste aanspreekpunt zijn voor het verrichten van mantelzorg. Echter, deze redenering bleek niet op te gaan voor andere relevante groepen, zoals vrouwen en mensen wier ouders in leven zijn. In overeenstemming met de verwachting gebaseerd op risico-inschatting vinden we dat hoger opgeleiden minder verantwoordelijkheid bij de overheid leggen dan laagopgeleiden; er blijkt echter geen verband te zijn tussen inkomen en attitudes.

Samenvattend kan gesteld worden dat met name voor het normatieve mechanisme en enigszins voor het utiliteitsmechanisme ondersteuning is gevonden. Er wordt minder verantwoordelijkheid voor zorg bij de overheid gelegd door mensen die sterke familiewaarden aanhangen, regelmatig naar de kerk gaan, zelf een goede gezondheid hebben, een groot potentieel steunnetwerk hebben en hoogopgeleid zijn. Vrouwen en mensen die nog een ouder in leven hebben, vinden zorg relatief sterker een taak voor de familie. De gestandaardiseerde coëfficiënten laten zien dat familiewaarden de meest bepalende determinant is (beta $=-0,184$ ).

5 Resultaten zijn gelijk als leeftijd niet lineair maar in categorieën wordt opgenomen in de analyse. 
Tabel 3: $\quad$ Determinanten van de attitude dat zorg voor hulpbehoevende ouderen vooral een taak voor de overheid (versus familie) is (ongestandaardiseerde en gestandaardiseerde regressiecoëfficiënten en robuuste standaardfouten verkregen uit OLS regressieanalyse)

\begin{tabular}{|c|c|c|c|}
\hline & b & r.se ${ }^{\text {a) }}$ & beta \\
\hline Intercept ${ }^{b)}$ & $0,738 * *$ & 0,028 & \\
\hline \multicolumn{4}{|l|}{ Periode: 2003 (ref) } \\
\hline $2006 / 07$ & $-0,024$ & 0,013 & $-0,016$ \\
\hline 2010 & $-0,161 * *$ & 0,017 & $-0,096$ \\
\hline Sterke familiewaarden & $-0,233 * *$ & 0,014 & $-0,184$ \\
\hline Kerkgang & $-0,102 * *$ & 0,015 & $-0,068$ \\
\hline Urbanisatiegraad & $-0,016 * *$ & 0,006 & $-0,030$ \\
\hline Leeftijd $(\times \mid 0)$ & 0,007 & 0,009 & 0,015 \\
\hline \multicolumn{4}{|l|}{ Situatie ouders: beide ouders overleden (ref) } \\
\hline Eén ouder in leven & $-0,051 *$ & 0,021 & $-0,030$ \\
\hline Beide ouders in leven & $-0,042$ & 0,025 & $-0,028$ \\
\hline Vrouw & $-0,080 * *$ & 0,017 & $-0,055$ \\
\hline \multicolumn{4}{|l|}{ Arbeidsparticipatie: niet werkzaam (ref) } \\
\hline Deeltijd werkend & $-0,007$ & 0,020 & $-0,004$ \\
\hline Voltijd werkend & 0,030 & 0,022 & 0,019 \\
\hline Gezondheid & $-0,026 * *$ & 0,010 & $-0,027$ \\
\hline Partner & $0,049 *$ & 0,020 & 0,028 \\
\hline Aantal kinderen & $-0,013 *$ & 0,006 & $-0,027$ \\
\hline Aantal broers en zussen & $-0,015 * *$ & 0,004 & $-0,052$ \\
\hline Netto maandelijks huishoudinkomen (× 100 Euro) ${ }^{c)}$ & $-0,001$ & 0,000 & $-0,015$ \\
\hline Opleidingsniveau in jaren & $-0,018 * *$ & 0,003 & $-0,076$ \\
\hline $\mathrm{R}^{2}$ & $5,5 \%$ & & \\
\hline
\end{tabular}

Bron: NKPS 2003, 2006/07, 2010 gecombineerd, ( $N=17.289)$, gewogen data

a) Robuuste standaardfouten vanwege clustering op uniek identificatienummer respondent (7.724 clusters)

b) Continue onafhankelijke variabelen zijn gecentreerd: leeftijd 50, middenpunt schaal familiewaarden, redelijk geürbaniseerd, goede gezondheid, 2 kinderen, 3 broers/zussen, inkomen van 2.000 euro per maand en 12 jaar opleiding

c) Tevens gecontroleerd voor dummy variabele die aangeeft of respondent oorspronkelijk een missende waarde had

$* p<0.05 ; * * p<0.01$

De verklaarde variantie van het model is overigens laag, hetgeen impliceert dat er ook andere determinanten moeten zijn. 
Tabel 4: $\quad$ Intra-individuele veranderingen in attitude ten aanzien van verantwoordelijkheid voor zorg voor hulpbehoevende ouderen tussen 2003 en 2006/07 en tussen 2006/07 en 2010

\begin{tabular}{lcccc}
\hline $\begin{array}{l}\text { Attitude t.a.v. verantwoordelijk- } \\
\text { heid voor zorg voor hulpbehoe- }\end{array}$ & Tussen $\mathbf{2 0 0 3}$ en $\mathbf{2 0 0 6 / 0 7}$ & Tussen 2006/07 en $\mathbf{2 0 ~ I 0 ~}$ \\
vende ouderen is... & $\%$ & $\mathrm{~N}$ & $\%$ & $\mathrm{~N}$ \\
\hline & 54,1 & 2.173 & 51,0 & 2.048 \\
Stabiel gebleven & 21,6 & 868 & 29,3 & 1.175 \\
Verschoven in de richting van familie & 24,3 & 975 & 19,7 & 793 \\
$\begin{array}{l}\text { Verschoven in de richting van over- } \\
\text { heid }\end{array}$ & 100 & 4.016 & 100 & 4.016 \\
Totaal & & & & \\
\hline
\end{tabular}

Bron: NKPS 2003, 2006/07, 2010; selectie op respondenten die aan 3 waves hebben deelgenomen $(N=4.016)$

\subsection{Intra-individuele verandering}

Veranderingen zijn tot nog toe uitgedrukt in een algemene trend onder de Nederlandse bevolking. Achter deze trend gaan echter individuele veranderingen schuil; deze worden getoond in tabel 4. Grofweg blijkt ongeveer de helft van de mensen niet van mening te zijn veranderd tussen twee meetmomenten. Daarnaast zien we dat er een substantiële groep is die - in overeenstemming met de algemene trend - tussen twee meetmomenten verschoven is in de richting van meer verantwoordelijkheid voor de familie: 21,6\% tussen 2003 en 2006/07 en 29,3\% tussen 2006/07 en 2010. Tegelijkertijd is er een substantiële groep die tijdens de onderzoeksperiode juist meer verantwoordelijkheid bij de overheid is gaan leggen: tussen 2003 en 2006/07 gaat het om 24,3\% en tussen 2006/07 en 2010 om 19.7\%. Vooral in de tweede periode is de richting naar meer verantwoordelijkheid voor familie dominant; de periode na de invoering van de Wmo. In de eerste periode zijn er juist meer mensen verschoven in de richting van overheidsverantwoordelijkheid.

De laatste te beantwoorden vraag is: welke factoren vergroten de kans dat men zorg meer is gaan zien als een taak voor de familie dan wel overheid? Tabel 5 rapporteert een drietal vergelijkingen: (1) de kans om opgeschoven te zijn in de richting van meer verantwoordelijkheid voor de overheid versus de kans om stabiel te zijn gebleven, (2) de kans om opgeschoven te zijn in de richting van meer verantwoordelijkheid voor familie versus de kans om stabiel te zijn gebleven, (3) de kans om opgeschoven te zijn in de richting van meer verantwoordelijkheid voor familie versus de overheid. Effecten zijn uitgedrukt in odds ratio's. Een odds ratio van 1 geeft aan dat er geen verband bestaat tussen de onafhankelijke variabele en de kans op een bepaalde verandering; odds ratio's groter dan 1 betekenen een grotere kans en odds ratio's kleiner dan 1 geven een kleinere kans aan. 
De periode-effecten reflecteren, conform de beschrijvingen in tabel 4, dat er in de tweede periode (tussen 2006/07 en 2010) relatief meer verschuivingen hebben plaatsgevonden in de richting van meer familieverantwoordelijkheid dan in de eerste periode (tussen 2003 en 2006/07), terwijl zich in de eerste periode juist meer verschuivingen richting overheidsverantwoordelijk hebben voorgedaan in vergelijking met de tweede periode. Zo geeft de odds ratio van 1,96 in Model 3 aan dat de kans om veranderd te zijn richting familie- versus overheidsverantwoordelijkheid in de periode 2006/07-2010 bijna twee keer zo groot was als in de periode 2003-2006/07. Dus na de invoering van de Wmo zijn er meer verschuivingen geweest in de door de overheid gewenste richting dan in de periode voor de Wmo-invoering. Het is noodzakelijk te controleren voor de attitude die een respondent bij aanvang van de periode had; dit verdisconteert namelijk de aanwezigheid van logische bodem- en plafondeffecten. De resultaten laten het bestaan daarvan duidelijk zien: mensen die de zorgtaak bij aanvang al sterk bij de overheid legden, hebben een kleinere kans om nog meer richting overheidsverantwoordelijk te schuiven en meer kans om richting familieverantwoordelijkheid te schuiven.

Van de normatieve factoren zijn de effecten van sterke familiewaarden en kerkgang zoals verwacht. Los van de opvatting ten aanzien van zorg aan de start van de periode, blijken mensen met sterke familiewaarden en regelmatige kerkgangers vaker veranderd te zijn in de richting van meer familieverantwoordelijkheid (ten opzichte van stabiele mensen en mensen die in de richting van overheidsverantwoordelijkheid zijn opgeschoven). Tevens zien we dat deze groepen minder kans hebben gehad te zijn opgeschoven in de richting van meer overheidsverantwoordelijkheid (ten opzichte van stabiel gebleven).

Verklarende factoren die geïnterpreteerd worden volgens het principe van eigenbelang, blijken nauwelijks samen te hangen met de kans dat een individu zijn of haar mening heeft aangepast over de tijd. Zo blijkt leeftijd niet significant samen te hangen met de kans dat attitude ten aanzien van ouderenzorg in een bepaalde richting is veranderd. Ook de situatie van de ouders, arbeidsparticipatie, gezondheid, het hebben van een partner, aantal kinderen, broers en zussen en huishoudinkomen vertonen geen significante effecten. Vrouwen zijn - tegen de verwachting van het utiliteitsprincipe in - vaker opgeschoven in de richting van familieverantwoordelijkheid voor ouderenzorg dan mannen (Model 2 en Model 3). Wel conform de verwachting is de bevinding dat hoogopgeleiden in vergelijking met laagopgeleiden niet verder opgeschoven zijn in de richting van overheidsverantwoordelijkheid; ze hebben meer kans stabiel te zijn gebleven (Model 1) en meer kans te zijn opgeschoven richting familieverantwoordelijkheid (Model 3).

Kortom, een attitudeverandering in lijn met de overheidsvisie is geconstateerd bij mensen met sterke familiewaarden, regelmatige kerkgangers, vrouwen en hoogopgeleiden. In termen van theoretische mechanismen suggereren deze resultaten dat de meeste verklarende kracht uitgaat van waardeoriëntaties. 
Tabel 5: $\quad$ Determinanten van de kans op intra-individuele verandering in attitude ten aanzien van zorg voor hulpbehoevende ouderen (odds ratio's en robuuste standaardfouten verkregen uit multinomiale regressieanalyse)

\begin{tabular}{|c|c|c|c|c|c|c|}
\hline & \multicolumn{2}{|c|}{$\begin{array}{l}\text { Model I: Veran- } \\
\text { derd richting } \\
\text { meer verantwoor- } \\
\text { delijkheid voor } \\
\text { overheid t.o.v. } \\
\text { stabiel gebleven }\end{array}$} & \multicolumn{2}{|c|}{$\begin{array}{l}\text { Model 2: Veran- } \\
\text { derd richting } \\
\text { meer verantwoor- } \\
\text { delijkheid voor } \\
\text { familie t.o.v. sta- } \\
\text { biel gebleven }\end{array}$} & \multicolumn{2}{|c|}{$\begin{array}{l}\text { Model 3: Veran- } \\
\text { derd richting } \\
\text { meer verantwoor- } \\
\text { delijkheid voor } \\
\text { familie t.o.v. meer } \\
\text { overheid }\end{array}$} \\
\hline & $\exp (b)$ & r.se a) & $\exp (b)$ & r.se a) & $\exp (b)$ & r.se a) \\
\hline Intercept ${ }^{b)}$ & $\mathrm{I}, 02$ & 0,17 & $0,09 * *$ & 0,16 & $0,09 * *$ & 0,22 \\
\hline \multicolumn{7}{|l|}{ Periode: $2003-2006 / 07$ (ref) } \\
\hline Periode: $2006 / 07-2010$ & $0,77 * *$ & 0,07 & $1,51 * *$ & 0,07 & $1,96 * *$ & 0,09 \\
\hline Attitude bij aanvang periode & $0,15 * *$ & 0,07 & $4,45 * *$ & 0,07 & $30,36 * *$ & 0,09 \\
\hline Sterke familiewaarden & $0,75 * *$ & 0,07 & $1,36 * *$ & 0,06 & $1,81 * *$ & 0,09 \\
\hline Kerkgang & $0,84 *$ & 0,08 & $\mathrm{I}, 14$ & 0,07 & $1,36 * *$ & 0,09 \\
\hline Urbanisatiegraad & 1,00 & 0,03 & $\mathrm{I}, 02$ & 0,03 & 1,02 & 0,04 \\
\hline Leeftijd $(\times \mid 0)$ & 1,06 & 0,05 & 1,00 & 0,04 & 0,94 & 0,06 \\
\hline \multicolumn{7}{|l|}{$\begin{array}{l}\text { Situatie ouders: beide } \\
\text { ouders overleden (ref) }\end{array}$} \\
\hline Eén ouder in leven & 1,06 & 0,11 & 0,93 & 0,09 & 0,87 & 0,12 \\
\hline Beide ouders in leven & 0,94 & 0,13 & $\mathrm{I}, 0 \mathrm{I}$ & 0,11 & $\mathrm{I}, 08$ & 0,15 \\
\hline Vrouw & 0,86 & 0,09 & $1,30 * *$ & 0,08 & $\mathrm{I}, 5 \mathrm{I} * *$ & 0,11 \\
\hline \multicolumn{7}{|l|}{$\begin{array}{l}\text { Arbeidsparticipatie: niet } \\
\text { werkzaam (ref) }\end{array}$} \\
\hline Deeltijd werkend & 1,00 & 0,11 & 0,93 & 0,10 & 0,94 & 0,13 \\
\hline Voltijd werkend & 1,06 & 0,12 & 0,94 & 0,11 & 0,89 & 0,15 \\
\hline Gezondheid & 0,94 & 0,05 & 1,00 & 0,05 & 1,06 & 0,07 \\
\hline Partner & 1,06 & 0,11 & 1,02 & 0,10 & 0,96 & 0,13 \\
\hline Aantal kinderen & $\mathrm{I}, 0 \mathrm{I}$ & 0,03 & $\mathrm{I}, 03$ & 0,03 & $\mathrm{I}, 03$ & 0,04 \\
\hline Aantal broers en zussen & 0,98 & 0,02 & $\mathrm{I}, 0 \mathrm{I}$ & 0,02 & $\mathrm{I}, 04$ & 0,02 \\
\hline $\begin{array}{l}\text { Netto maandelijks huishoud- } \\
\text { inkomen }(\times 100 \text { Euro })^{c)}\end{array}$ & 1,00 & 0,00 & 1,00 & 0,00 & $\mathrm{I}, 00$ & 0,00 \\
\hline Opleidingsniveau in jaren & $0,95 * *$ & 0,01 & 0,99 & 0,01 & $\mathrm{I}, 03 *$ & 0,02 \\
\hline
\end{tabular}

Bron: NKPS 2003, 2006/07, 2010 gecombineerd; ( $N=4.016$ respondenten, $N=8.032$ observaties), gewogen data

a) Robuuste standaardfouten vanwege clustering op uniek identificatienummer respondent (4.016 clusters)

b) Continue onafhankelijke variabelen zijn gecentreerd: leeftijd 50 , middenpunt schaal familiewaarden, redelijk geürbaniseerd, goede gezondheid, 2 kinderen, 3 broers/zussen, inkomen van 2.000 euro per maand en 12 jaar opleiding

c) Tevens gecontroleerd voor dummy variabele die aangeeft of respondent oorspronkelijk een missende waarde had

$*_{\mathrm{p}}<0.05 ; * * \mathrm{p}<0.0$ I 


\section{Conclusie en discussie}

Dit artikel beschrijft ontwikkelingen tussen 2003 en 2010 in de publieke opinie aangaande de verantwoordelijkheid voor zorg voor hulpbehoevende ouderen; onderzoekt welke factoren verklaren dat sommige mensen deze verantwoordelijkheid vooral bij de overheid en anderen bij de familie leggen; en gaat na welke factoren verklaren waarom mensen hun mening hebben aangepast. De Nederlandse overheid streeft een participatiesamenleving na. In het zorgbeleid staat eigen verantwoordelijkheid van de burger steeds meer centraal: zorg moet in eerste instantie niet geleverd worden door de staat, maar door de eigen omgeving. De publieke opinie is in deze zelfde richting aan het opschuiven. Steeds minder mensen vinden dat de zorg voor ouderen vooral een taak van de overheid is; er vindt een verschuiving plaats in de richting van verantwoordelijkheid voor de familie. Deze bevinding suggereert dat draagvlak voor de gekozen insteek van de overheid toeneemt. Echter, deze conclusie moet gepaard gaan met de belangrijke nuancering dat nog steeds de meerderheid van de Nederlandse bevolking de zorgtaak voor ouderen het meest bij de overheid legt. De door de overheid gewenste mentaliteitsverandering is nog verre van voltooid.

Onderzoek naar ontwikkelingen in de publieke opinie aangaande verantwoordelijkheid in de zorg betekende een bijdrage aan de bestaande literatuur over dit onderwerp. Dit onderzoek kan echter niet aantonen of de gewijzigde insteek van het overheidsbeleid - met de toenemende nadruk op het vinden van zorg in eigen kring voordat formele zorg wordt ingezet - de reden is voor de verandering in de publieke opinie. Wel is duidelijk geworden dat compositieveranderingen in de bevolking niet verantwoordelijk zijn voor de verschuiving in publieke opinie en dat de sterkste verandering in de richting van meer eigen verantwoordelijkheid zich heeft voorgedaan in de periode na invoering van de Wmo. Voor zover er een socialiserende werking van overheidsbeleid uitgaat, kan verwacht worden dat steun voor eigen verantwoordelijkheid verder zal toenemen met de verdere aanscherping en uitbreiding van eigen verantwoordelijkheid in de zorg en het sociale domein. Echter, de constatering dat in de periode na invoering van de Wmo nog steeds een aanzienlijk deel van de bevolking haar mening heeft aangepast in tegengestelde richting (dat wil zeggen, meer verantwoordelijkheid bij de overheid is gaan leggen), geeft aan dat beleidsinvloeden niet de enige reden kunnen zijn voor de (voorzichtige) mentaliteitsverandering; er moeten ook individuele verklaringen zijn.

Individuele verklaringen zijn op twee manieren aan bod gekomen in dit onderzoek: enerzijds is nagegaan welke factoren samenhangen met attituden over verantwoordelijkheid van zorg, anderzijds is nagegaan welke factoren de kans beïnvloeden dat een individu zijn attitude heeft aangepast. De resultaten ondersteunen het theoretische idee dat algemene waardeoriëntaties bepalen hoe mensen aankijken tegen het specifieke geval van taakverdeling in de zorg van hulpbehoevende ouderen en dat een 'traditionele' blik op de rol van familie aansluit bij de huidige ideeën van de overheid. Zorg voor ouderen wordt relatief minder 
gezien als taak voor de overheid door mensen met sterke familiewaarden en mensen die regelmatig naar de kerk gaan. Naast normatieve motieven zijn er ook aanwijzingen voor utiliteitsmotieven bij de totstandkoming van attituden over verantwoordelijkheid voor zorg, maar niet alle verwachte mechanismen van eigenbelang blijken relevant. Er zijn geen aanwijzingen dat mensen die redelijkerwijs nu of in de toekomst kunnen verwachten dat ze een beroep zullen moeten doen op zorg (ouderen) of dat er een mantelzorgberoep op hen wordt gedaan (mensen met ouders in leven en vrouwen), meer geneigd zijn de verantwoordelijkheid voor zorg bij de overheid te leggen. Daarentegen gaat gebrek aan hulpbronnen om mantelzorg te kunnen verlenen wel samen met meer steun voor overheidsverantwoordelijkheid, voor zover het gaat om een slechte gezondheid en een klein netwerk van potentiële steunverleners (broers, zussen, kinderen); beperkingen in tijd door arbeidsparticipatie blijken niet van invloed. Ten slotte is er enige ondersteuning voor het idee dat mensen die eventuele negatieve consequenties van eigen verantwoordelijkheid beter kunnen dragen, minder afkering van zijn van familieverantwoordelijkheid voor ouderenzorg: opleidingsniveau blijkt een significante factor, maar inkomen niet. Wat betekent deze kennis over determinanten voor beleid? Enerzijds vergroot het het inzicht welke groepen ver van de huidige overheidsvisie afstaan en welke relatief dichtbij. Anderzijds geeft het inzicht in waar draagvlak voor de participatiesamenleving vandaan komt. Dit onderzoek suggereert dat publieke steun sterker gestuurd wordt door waardeorientaties dan utiliteitsoverwegingen. Interessant zou zijn om te onderzoeken of deze balans er anders uitziet als het gaat om gedrag in lijn met het ingezette overheidsbeleid. Mogelijkerwijs wordt gedrag meer gestuurd door eigenbelang dan opvattingen.

De verklaringskracht van alle determinanten samen bleek gering. Een belangrijke alternatieve verklaring is een andere vorm van waardeoriëntatie: politieke overtuiging. Eerder onderzoek heeft aangetoond dat opvattingen over verantwoordelijkheid voor zorg tevens sterk samenhangen met politieke overtuiging (Den Ridder \& Dekker, 2012; Durant \& Legge, 2002), met name het traditionele onderscheid tussen een voorkeur voor relatief veel overheidsbemoeienis (politiek links) of voor weinig overheidsbemoeienis (politiek rechts). Deze vorm van waardeoriëntaties kon wegens gebrek aan informatie over politieke overtuigingen in de data helaas niet getoetst worden, maar het is dus niet uitgesloten dat de impact van normatieve factoren op attitudevorming over dit specifieke onderwerp groter is dan blijkend uit dit onderzoek.

Uit de tweede analyse van individuele verklaringen is gebleken dat de kans op een attitudeverandering in de richting van minder overheid- en meer familieverantwoordelijkheid groter is bij mensen met sterke familiewaarden, regelmatige kerkgangers, vrouwen en hoogopgeleiden. De algemene suggestie is dan ook dat individuele attitudeveranderingen sterker afhankelijk zijn van waardeoriëntatie dan van persoonlijke omstandigheden die eigen verantwoordelijkheid uit eigenbelang minder aantrekkelijk maken. Deze conclusie sluit aan bij de visie van Tonkens en Duyvendak (2013) die stellen dat als de overheid burgers meer eigen verantwoor- 
delijkheid wil laten nemen, ze dit vooral moet proberen te bereiken door in te spelen op de gevoelens van burgers, aangezien gewenst gedrag belonen (dus inspelen op eigenbelang) niet haalbaar is wegens gebrek aan financiële middelen en zondermeer afdwingen van eigen verantwoordelijkheid niet effectief is vanwege gebrek aan legitimiteit. De vraag of de geobserveerde trend zich in de nabije toekomst zal doorzetten en het draagvlak voor het ingezette overheidsbeleid verder zal toenemen is natuurlijk mede afhankelijk van hoe effectief de overheid op deze gevoelens kan inspelen. Van veranderingen in de samenstelling van de bevolking zou echter een natuurlijke remmende werking kunnen uitgaan op een verdere mentaliteitsverschuiving in de richting van minder overheidsverantwoordelijkheid: sterke familiewaarden en kerkgang komen met de vervanging van oude door nieuwe generaties steeds minder in de samenleving voor, terwijl het juist deze groepen zijn die hun mening blijken te hebben aangepast in de richting van minder overheid- en meer familieverantwoordelijkheid.

\section{Literatuur}

Battaglio, R.P., Privatization and citizen preferences. A cross-national analysis of demand for private versus public provision of services in three industries, Administration \& Society, 2009/1, p. 38-66.

Boer, A. de, M. Broese van Groenou \& J. Timmermans, Mantelzorg. Een overzicht van de steun van en aan mantelzorgers in 2007, Den Haag: 2010.

Boer, A. de \& S. Kooiker, Zorg, V. Veldheer, J.J. Jonker, L. van Noije \& C. Vrooman (eds.), Een beroep op de burger. Minder verzorgingsstaat, meer eigen verantwoordelijkheid? Sociaal en Cultureel Rapport 2012, Den Haag: 2012, p. 140-160

Beetham, D., The legitimation of power, New York: 1991.

Dekker, P. \& J. den Ridder, Meer eigen verantwoordelijkheid in de publieke opinie. Wat willen Nederlanders?, T. Kampen, T., I. Verhoeven \& L. Verplanke (eds.), De affectieve burger, Amsterdam: 2013, p. 41-60,.

Dekker, P. \& J. den Ridder, Burgerperspectieven. Kwartaalbericht 2011/3, Den Haag: 2011.

Dohmen, A., E, Verbakel \& G. Kraaykamp, Sociaal vertrouwen in de Europese context. Een multiniveauanalyse met 18 landen, Mens en Maatschappij, 2010/2, p. 154-175.

Durant, R.F. \& J.S. Legge, Politics, public opinion, and privatization in France. Assessing the calculus of consent for market reforms, Public Administration Review, 2002/3, p. 307-323.

Dykstra, P.A., M. Kalmijn, T.C.M. Knijn, A.E. Komter, A.C. Liefbroer \& C.H. Mulder, Codebook of the Netherlands Kinship Panel Study, a multi-actor, multi-method panel study on solidarity in family relationships, Wave 1. NKPS Working Paper No. 4, Den Haag: 2005.

Dykstra, P.A., M. Kalmijn, T.C.M. Knijn, A.E. Komter, A.C. Liefbroer \& C.H. Mulder, Codebook of the Netherlands Kinship Panel Study, a multi-actor, multi-method panel study on solidarity in family relationships, Wave 2. NKPS Working Paper No. 8, Den Haag: 2012.

Felling, A., J. Peters \& P. Scheepers (eds.), Individualisering in Nederland aan het eind van de twintigste eeuw, Assen: 2000.

Glenn, N. D., Values, attitudes, and beliefs, O.G Brim \& J. Kagan (eds.), Constancy and change in human development, p. 596-640, Cambridge MA: 1980.

Halman L., Individualism in individualized society? Results from the European Values Surveys, International Journal of Comparative Sociology, 1996/3-4, p. 195-214.

Kampen, T., I. Verhoeven \& L. Verplanke (eds.), De affectieve burger, Amsterdam: 2013. 
Klerk, M. de, R. Gilsing \& J. Timmermans (eds.), Op weg met de WMO. Evaluatie van de Wet maatschappelijke ondersteuning 2007-2009, Den Haag: 2010.

Merz, E.-M., P.A. Dykstra, M.J.A. Hogerbrugge, A.E. Komter, A.C. Liefbroer \& C.H. Mulder, Codebook of the Netherlands Kinship Panel Study, a multi-actor, multi-method panel study on solidarity in family relationships, Wave 3. NKPS Working Paper No. 10, Den Haag: 2012.

Ministerie van Binnenlandse Zaken en Koninkrijksrelaties (2013). Decentralisatiebrief, 19 februari 2013. http://www.rijksoverheid.nl/documenten-en-publicaties/ kamerstukken/2013/02/19/kamerbrief-aanpak-decentralisaties-op-terrein-vanondersteuning-participatie-en-jeugd.html

Newton, K., Social capital and democracy in modern Europe, J.W. van Deth, M. Maraffi, K. Newton \& P.F. Whiteley (eds.), Social capital and European democracy, Londen: 1999, p. 3-24.

Noije, L. van, J.J. Jonker, V. Veldheer \& C. Vrooman, Verschuivende verantwoordelijkheden, V. Veldheer, J.J. Jonker, L. van Noije \& C. Vrooman (eds.), Een beroep op de burger. Minder verzorgingsstaat, meer eigen verantwoordelijkheid? Sociaal en Cultureel Rapport 2012, Den Haag: 2012, p. 303-322.

Pinquart, M. \& S. Sörensen, Differences between caregivers and noncaregivers in psychological health and physical health: A meta-analysis, in: Psychology and Aging, 2003, nr. 18, p. 250-267.

Putnam, R. D., Bowling alone. The collapse and revival of American community, New York: 2000.

Ridder, J. den \& P. Dekker, De publieke opinie over eigen verantwoordelijkheid, V. Veldheer, J.J. Jonker, L. van Noije \& C. Vrooman (eds.), Een beroep op de burger. Minder verzorgingsstaat, meer eigen verantwoordelijkheid? Sociaal en Cultureel Rapport 2012, Den Haag: 2012, p. 277-302.

Rosenthal, C.J., Kinkeeping in the familial division of labor, Journal of Marriage and the Family, 1985/4, p. 965-974.

Rossi, A.S. \& P.H. Rossi, Of human bonding. Parent-child relations across the life course, New York: 1990.

Sadiraj K., J. Timmermans, M. Ras \& A. de Boer, De toekomst van de mantelzorg, Den Haag: 2009.

Tonkens, E., The embrace of responsibility. Citizenship and governance of social care in the Netherlands, J. Newman \& E. Tonkens (eds.), Participation, responsibility and choice, Amsterdam: 2011, p. 45-64.

Tonkens, E. \& J.W. Duyvendak, Een hardnekkige affectieve revolutie, T. Kampen, I. Verhoeven \& L. Verplanke (eds.), De affectieve burger, Amsterdam: 2013. p. 233-248.

Van Meter, D.S. \& C.E. Van Hom, The policy implementation process. A conceptual framework, Administration \& Society, 1975/4, p. 445-488. 